LOCKHEED MATTIN

ENVIRONMENTAL RESTORATION PROGRAM

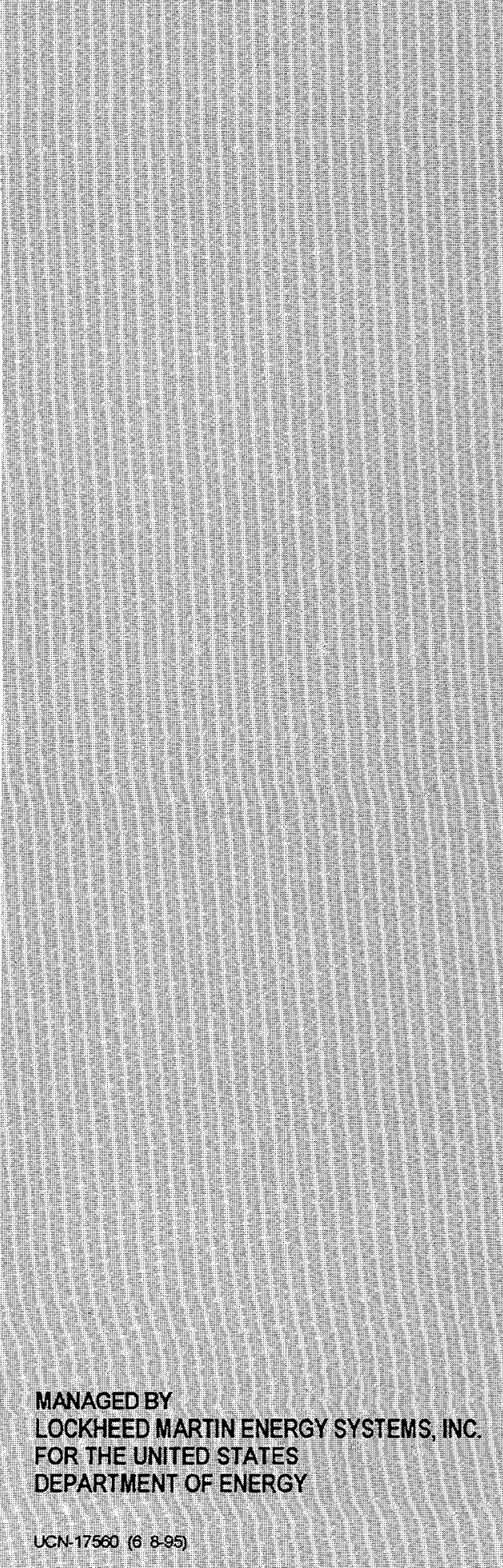

\section{RECEIVED}

\section{JAN 231997}

Y/ER-279

\title{
Wetland Survey of Selected Areas in the Oak Ridge Y-12 Plant Area of Responsibility, Oak Ridge, Tennessee
}

\section{MASTER}

\section{DISTRIBUTION OF THIS DOCUMENT IS UNLAMTED}

\section{lin}

This document has been approved by the Y-12 Plant Technical Information Office for release to the public. Date: $1 / 15 / 97$

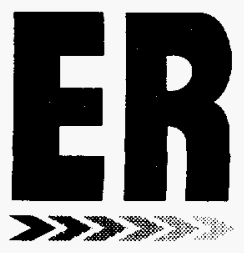




\section{JAYCOR Environmental}

contributed to the preparation of this document and should not be considered an eligible contractor for its review. 
Energy Systems Environmental Restoration Program

\title{
Wetland Survey of Selected Areas in the Oak Ridge Y-12 Plant Area of Responsibilty, Oak Ridge, Tennessee
}

\author{
B. A. Rosensteel \\ Date Issued—January 1997 \\ Prepared by \\ JAYCOR Environmental \\ Oak Ridge, Tennessee \\ under general order agreement 28B99230C-X07 \\ Prepared for the \\ U.S. Department of Energy \\ Office of Environmental Management \\ under budget and reporting code EW 20 \\ Environmental Management Activities at the \\ OAK RIDGE Y-12 PLANT \\ Oak Ridge, Tennessee 37831 \\ managed by \\ LOCKHEED MARTIN ENERGY SYSTEMS, INC. \\ for the \\ U.S. DEPARTMENT OF ENERGY \\ under contract DE-AC05-84OR21400
}




\section{DISCLAIMER}

Portions of this document may be illegible in electronic image products. Images are produced from the best available original document. 


\section{DISCLAIMER}

This report was prepared as an account of work sponsored by an agency of the United States Government. Neither the United States Government nor any agency thereof, nor any of their employees, make any warranty, express or implied, or assumes any legal liability or responsibility for the accuracy, completeness, or usefulness of any information, apparatus, product, or process disclosed, or represents that its use would not infringe privately owned rights. Reference herein to any specific commercial product, process, or service by trade name, trademark, manufacturer, or otherwise does not necessarily constitute or imply its endorsement, recommendation, or favoring by the United States Government or any agency thereof. The views and opinions of authors expressed herein do not necessarily state or reflect those of the United States Government or any agency thereof. 


\section{PREFACE}

Wetland Survey of Selected Areas in the Oak Ridge Y-12 Plant Area of Responsibility, Oak Ridge, Tennessee (Y/ER-279) was prepared as a summary of wetland surveys performed in the Y-12 Plant area of responsibility in June and July 1994. This work was performed under Work Breakdown Structure 1.4.12.2.3.04.02.01, Activity Data Sheet 8300). This document provides the management of the Y-12 Plant and the Environmental Restoration Program with an overview of the wetland areas at the Y-12 Plant. 


\section{CONTENTS}

PREFACE $\ldots \ldots \ldots \ldots \ldots \ldots \ldots \ldots \ldots \ldots \ldots \ldots \ldots \ldots \ldots \ldots \ldots \ldots \ldots \ldots$

FIGURES $\ldots \ldots \ldots \ldots \ldots \ldots \ldots \ldots \ldots \ldots \ldots \ldots \ldots \ldots \ldots \ldots \ldots$

TABLES $\ldots \ldots \ldots \ldots \ldots \ldots \ldots \ldots \ldots \ldots \ldots \ldots \ldots \ldots \ldots \ldots \ldots \ldots \ldots$

ABBREVIATIONS $\ldots \ldots \ldots \ldots \ldots \ldots \ldots \ldots \ldots \ldots \ldots \ldots \ldots \ldots \ldots \ldots \ldots$

EXECUTIVE SUMMARY $\ldots \ldots \ldots \ldots \ldots \ldots \ldots \ldots \ldots \ldots \ldots \ldots \ldots \ldots \ldots \ldots$ vii

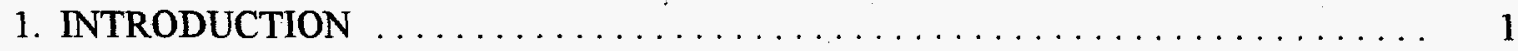

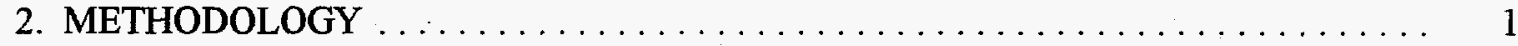

2.1 WETLAND IDENTIFICATION METHODOLOGY $\ldots \ldots \ldots \ldots \ldots \ldots \ldots \ldots$

2.1.1 The U.S. Army Corps of Engineers Wetland Delineation Methodology . . . . . . 1

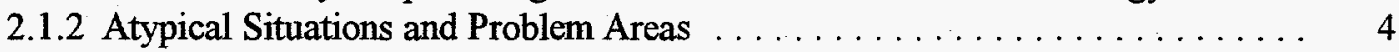

2.2 WETLAND CLASSIFICATION $\ldots \ldots \ldots \ldots \ldots \ldots \ldots \ldots \ldots \ldots \ldots$

3. WETLAND SURVEY FINDINGS $\ldots \ldots \ldots \ldots \ldots \ldots \ldots \ldots \ldots \ldots \ldots$

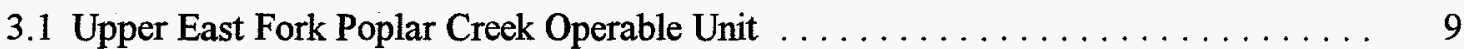

3.1.1 Southeast Side of Bear Creek Road (Y-12 Main Plant Area) . . . . . . . . . 10

3.1.2 Northwest Side of Bear Creek Road ... . . . . . . . . . . . . . . . . . 11

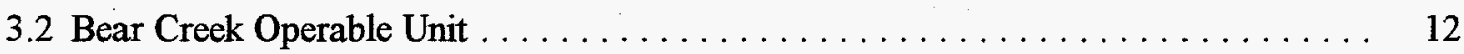

3.3 Chestnut Ridge Operable Unit 2 - McCoy Branch South of Bethel Valley Road . . . . 13

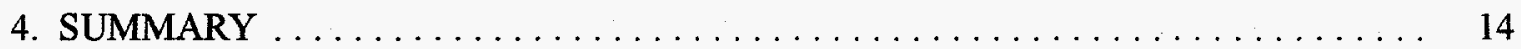

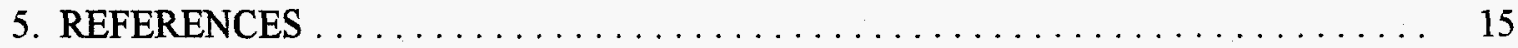

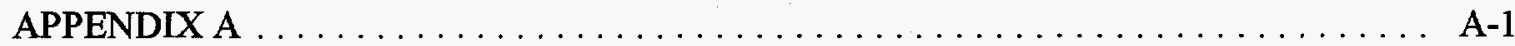




\section{FIGURES}

1 Wetland areas in the southwestern half of the Upper East Fork Poplar Creek Operable Unit and a portion of the Bear Creek Operable Unit

2 Wetland areas in the northeastern half of the Upper East Fork Poplar Creek Operable Unit

3 Wetland areas in the Chestnut Ridge Operable Unit 2, south of Bethel Valley Road

\section{TABLES}

1 Plant indicator classifications and frequency of occurrence in wetlands (Reed 1988)

2 List of some of the dominant and common plant species and their wetland indicator classifications (Reed, 1988) identified during the wetland survey of selected areas within the Y-12 Area of Responsibility

3 Classification and approximate areal size of wetlands identified in selected areas of the Y-12 Plant area of responsibility 
ABBREVIATIONS

$\begin{array}{ll}\text { BCNT } & \text { Bear Creek North Tributary } \\ \text { FPC } & \text { East Fork Poplar Creek } \\ \text { FAC } & \text { facultative } \\ \text { FAC } & \text { facultative upland } \\ \text { FAC } & \text { facultative wetland } \\ \text { NPDES } & \text { National Pollution Discharge Elimination System } \\ \text { OBI } & \text { obligate } \\ \text { OU } & \text { Operable Unit } \\ \text { TDEC } & \text { Tennessee Department of Environment and Conservation } \\ \text { UEFPC } & \text { Upper East Fork Poplar Creek } \\ \text { UPU } & \text { upland } \\ \text { USACE } & \text { United States Army Corps of Engineers }\end{array}$

vi 


\section{EXECUTIVE SUMMARY}

This document was prepared to summarize wetland surveys performed in the Y-12 Plant area of responsibility in June and July 1994. Wetland surveys were conducted in three areas within the Oak Ridge Y-12 Plant area of responsibility in June and July 1994: the Upper East Fork Poplar Creek (UEFPC) Operable Unit (OU), part of the Bear Creek Valley OU (the upper watershed of Bear Creek from the culvert under Bear Creek Road upstream through the Y-12 West End Environmental Management Area, and the catchment of Bear Creek North Tributary 1), and part of Chestnut Ridge OU 2 (the McCoy Branch area south of Bethel Valley Road).

Using the criteria and methods set forth in the Wetlands Delineation Manual [U.S. Army Corps of Engineers (USACE) 1987], 18 wetland areas were identified in the 3 areas surveyed; these areas were classified according to the system developed by Cowardin et al. (1979).

Fourteen wetlands and one wetland/pond area that are associated with disturbed or remnant stream channels and seeps were identified in the UEFPC OU. Three wetlands were identified in the Bear Creek Valley OU portion of the survey area. One wetland was identified in the riparian zone of McCoy Branch in the southern portion of Chestnut Ridge OU 2. 


\section{INTRODUCTION}

Wetland surveys were conducted in the following areas within the Oak Ridge Y-12 Plant area of responsibility in June and July 1994:

- Upper East Fork Poplar Creek (UEFPC) Operable Unit (OU) consisting of the Y-12 main plant area between Pine Ridge and Chestnut Ridge.

- A portion of the Bear Creek Valley OU consisting of the upper watershed of Bear Creek from the culvert under Bear Creek Road upstream through the Y-12 West End Environmental Management Area, and the catchment of Bear Creek North Tributary 1.

- A portion of Chestnut Ridge OU 2 consisting of the McCoy Branch area south of Bethel Valley Road.

A total of eighteen wetland areas were identified in the three areas. Fourteen wetlands and one wetland/pond area that are associated with disturbed or remnant stream channels and seeps were identified in the UEFPC OU. Three wetlands were identified in the Bear Creek Valley OU portion of the survey area. One wetland was identified in the riparian zone of McCoy Branch in the southern portion of Chestnut Ridge OU 2.

\section{METHODOLOGY}

\subsection{WETLAND IDENTIFICATION METHODOLOGY}

\subsubsection{The U. S. Army Corps of Engineers Wetland Delineation Methodology}

As required by the Energy and Water Development Appropriations Act of 1992, wetlands are identified using the criteria and methods set forth in the Wetlands Delineation Manual [U.S. Army Corps of Engineers (USACE) 1987]. USACE defines wetlands as "those areas that are inundated or saturated by surface or ground water at a frequency and duration sufficient to support, and that under normal circumstances do support, a prevalence of vegetation typically adapted for life in saturated soil conditions."

The USACE lists three characteristics that are diagnostic of wetlands: (1) The vegetation is characterized by a prevalence of macrophytes typically adapted to wetland soil and hydrological conditions, (2) the substrate is undrained hydric soil, and (3) the area is inundated either permanently or periodically at depths less than $2 \mathrm{~m}(6.6 \mathrm{ft})$ or the soil is saturated to the surface at some time during the growing season of the prevalent vegetation. 


\subsubsection{Hydrophytic vegetation}

USACE (1987) defines hydrophytic vegetation as "the sum total of macrophytic plant life that occurs in areas where the frequency and duration of inundation or soil saturation produce permanently or periodically saturated soils of sufficient duration to exert a controlling influence on the plant species present." The U.S. Fish and Wildlife Service (Reed 1988) has developed a classification system that assigns species to wetland indicator classes according to the frequency with which a species occurs in a wetland (Table 1). If more than $50 \%$ of the vegetation in each strata (i.e., canopy, sapling/shrub, vines, herbaceous) have an indicator status of obligate (OBL), facultative wetland (FACW), and/or facultative (FAC), the vegetation is classified as hydrophytic. A positive $(+)$ or negative $(-)$ sign following any of the facultative indicator categories indicates a frequency toward the higher end of the category (more frequently found in wetlands) or the lower end of the category (less frequently found in wetlands), respectively.

Table 1. Plant indicator classifications and frequency of occurrence in wetlands

\begin{tabular}{cc}
\hline Classification & $\begin{array}{c}\text { Occurrence in wetlands } \\
(\%)\end{array}$ \\
\hline Obligate wetland (OBL) & $>99$ \\
Facultative wetland (FACW) & $67-99$ \\
Facultative (FAC) & $34-66$ \\
Facultative upland (FACU) & $1-33$ \\
Upland (UPL) & $<1$ \\
\hline
\end{tabular}

Source: P. B. Reed. 1988. National List of Plant Species that Occur in Wetlands: Tennessee. USFWS Biological Report NERC-88/18.42. U.S. Fish and Wildlife Service, Washington, D.C.

\subsubsection{Hydric soils}

Hydric soils are soils that are saturated, flooded, or ponded long enough during the growing season to develop anaerobic conditions in a major part of the root zone. The following indicators are used to determine whether a given nonsandy soil meets the definition and criteria for hydric soils:

- Organic soils. Organic soils are ones in which more than $50 \%$, by volume, of the upper $82 \mathrm{~cm}$ (32 in.) of soil is composed of organic soil material. Organic soils are saturated for long periods and are commonly called peats or mucks.

- Sulfidic material. The presence of a rotten egg odor is indicative of the presence of hydrogen sulfide, which is produced only in a reducing environment (e.g., saturated, waterlogged soils).

- Aquic or peraquic moisture regime. Aquic moisture regimes are ones in which the soils are virtually free of dissolved oxygen because of saturation by groundwater or water of the capillary fringe. Peraquic moisture regimes are characterized by the presence of groundwater always at or near the soil surface. 
- Iron and manganese concretions. These concretions are formed during the oxidation-reduction process. Concretions less than $2 \mathrm{~mm}$ in diameter occurring within $7.5 \mathrm{~cm}$ of the surface are evidence that the soil is saturated for long periods near the surface.

- Soil colors. Soil colors are often the most diagnostic indicator of hydric soils. Mineral hydric soils either will be gleyed (bluish, greenish, or grayish colors resulting from chemical reduction under anaerobic conditions) or will have bright mottles (speckles of oxidized iron indicative of fluctuating water table and alternating anaerobic and aerobic conditions) and a low chroma matrix.

Munsell Soil Color Charts (Kollmorgen Instrument Corp. 1990) were used to determine soil colors. The Munsell notation for color consists of separate notations for hue, value, and chroma. The hues are R (red), YR (yellow-red), and Y (yellow) and refer to the soil color in relation to the primary colors (red, yellow, and blue). The hues are further defined by the numbers 2.5, 5.0, 7.5, and 10 preceding the hue designation. The numbers indicate the gradation from red through yellow within each hue with 2.5 being more red and 10 being more yellow. The value notation refers to the lightness of the hue and ranges from 0 (absolute black) to 10 (absolute white). Chroma refers to the strength, or saturation, of the color and ranges from 0 (neutral gray) to 8 .

In writing Munsell color notations, the sequence is always hue, value, and chroma. For instance, 10YR 5/2 indicates a soil on the yellow end of the yellow-red hue with a value of 5 (mid-range) and a chroma of 2 . Each Munsell notation corresponds to a color. For example, 10YR 5/2 is grayishbrown. Mineral hydric soils have one of the following features in the horizon immediately below the A-horizon or between 0 and $25.6 \mathrm{~cm}$ (10 in.), whichever is shallower: (1) A matrix chroma of 2 or less in mottled soils or (2) a matrix chroma of 1 or less in unmottled soils.

Not all of the indicators listed above can be used in sandy soils because hydric features develop more slowly in sandy soils. Soil colors, in particular, should not be used as an indicator in most sandy soils. Hydric indicators for sandy soils include the following:

- high organic matter content in the surface horizon;

- streaking of subsurface horizons by organic matter; and

- organic pans, which are accumulations of organic matter at the point representing the most commonly occurring depth to the water table.

In areas of sediment mixing and deposition; such as accreting sandbars and floodplains, indicators of hydric soil may not have time to develop within the upper $25.6 \mathrm{~cm}$ of the soil. For the purposes of wetland determinations, these sites are treated according to guidelines for atypical situations and problem areas as described in Sect. 2.1.2.

\subsubsection{Wetland hydrology}

Of the three technical criteria, wetland hydrology is generally the least exact. Field indicators are useful for confirming wetland presence but are unreliable for delineating precise wetland boundaries. Indicators of wetland hydrology include recorded data (e.g., aerial photographs, soil surveys, floodplain delineations) and field evidence, such as drainage patterns (surface scouring, absence of leaf litter, eroded soil, and drift lines), sediment deposition, watermarks, visual observation of either inundation or saturated soils or both, and oxidized rhizospheres. 


\subsubsection{Atypical Situations and Problem Areas}

The USACE Wetlands Delineation Manual (1987) addresses atypical situations and problem areas in which one or more positive indicators of wetland presence may be absent in a wetland and describes procedures for determining if the area in question is a wetland. Atypical situations are those in which positive indicators of either hydrophytic vegetation, hydric soils, or wetland hydrology are absent because of effects of recent human activities or natural events. Atypical situations include areas in which there are unauthorized discharges requiring enforcement actions; natural events such as changing river courses, beaver dams, mudslides, and earthquakes; and human-induced wetlands that have been purposely or incidentally created by human activities. Problem areas are those "wetland types in which wetland indicators of one or more parameters may be periodically lacking due to normal seasonal or annual variations in environment conditions that result from causes other than human activities or catastrophic natural events" (USACE 1987). Problem area wetlands include seasonal wetlands (wetland hydrology is absent during dry seasons), prairie potholes (wetland hydrology is absent during dry years), and vegetated flats (vegetation is absent during the nongrowing season).

\subsection{WETLAND CLASSIFICATION}

The wetlands identified in this survey were classified according to the system developed by Cowardin et al. (1979) for wetland and deep water habitats of the United States. This hierarchical system describes wetlands and deep water habitats by system, class, and subclass. Additional modifiers are added for water regime, chemistry, soil, and disturbances. The systems are marine, estuarine, riverine, lacustrine, and palustrine. The marine and estuarine systems are oceanic and coastal and thus do not occur on the Oak Ridge Reservation. The lacustrine and riverine systems encompass freshwater lakes and rivers/streams respectively. The palustrine systems includes nontidal wetlands dominated by trees, shrubs, persistent emergents, and/or emergent mosses or lichens and includes vegetated wetlands traditionally called by such names as marsh, swamp, bog, fen, and pond.

The palustrine system includes five classes that are vegetated and are thus considered wetlands under the USACE definition (1987): (1) Aquatic bed (dominated by submerged or floating plants), (2) moss-lichen, (3) emergent (dominated by herbaceous plants that rise above the water surface), (4) scrub-shrub (dominated by shrubs and saplings), and (5) forested. Subclasses of the vegetated classes indicate differences in vegetative form, such as broad-leaved or needle-leaved, deciduous or evergreen, and persistent (species that normally remain standing at least until the beginning of the next growing season) or nonpersistent (plants that fall to the surface of the substrate or below the surface of the water at the end of the growing season).

\section{WETLAND SURVEY FINDINGS}

Figures 1 and 2 show the wetland survey areas and the approximate boundaries of the wetlands in the UEFPC OU and that portion of the Bear Creek Valley OU included in this survey. Figure 3 shows the approximate boundary of the wetland identified in the southern portion of Chestnut Ridge

OU 2. The wetland boundaries have not been marked in the field nor located by civil survey. The boundary locations were estimated to follow or parallel the nearest 20 - $\mathrm{ft}$ contour line on the Oak Ridge Reservation S16-A map. Thus, both the wetland boundaries and the areal sizes are approximate. 


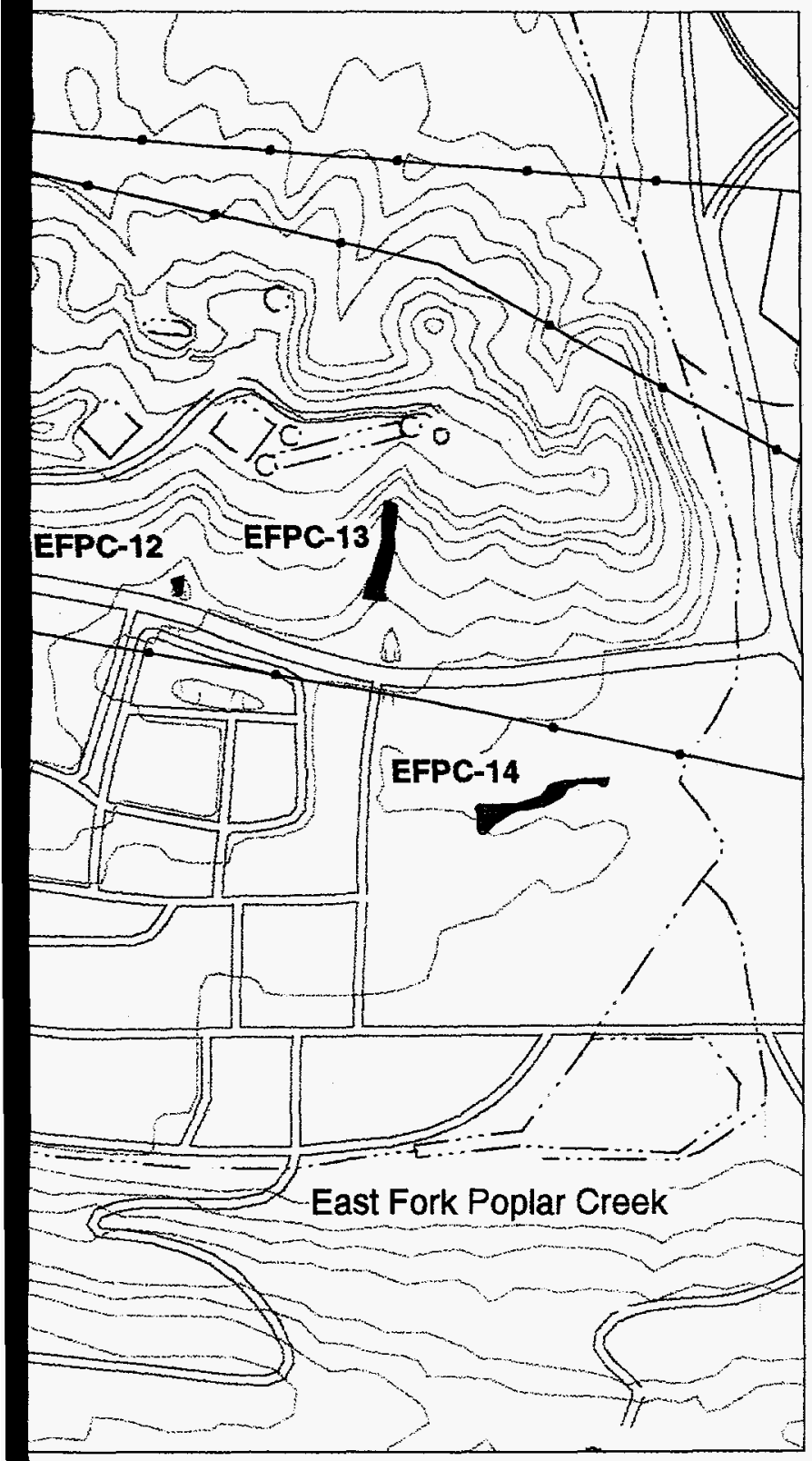

Ridge Reservation, Oak Ridge, Tennessee.

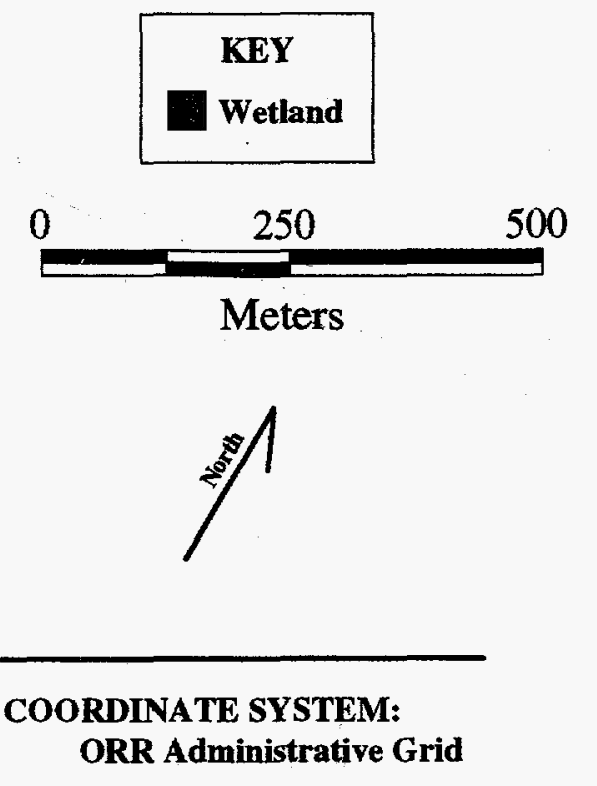

BASE DATA:

ORNL Shared Data Initiative 


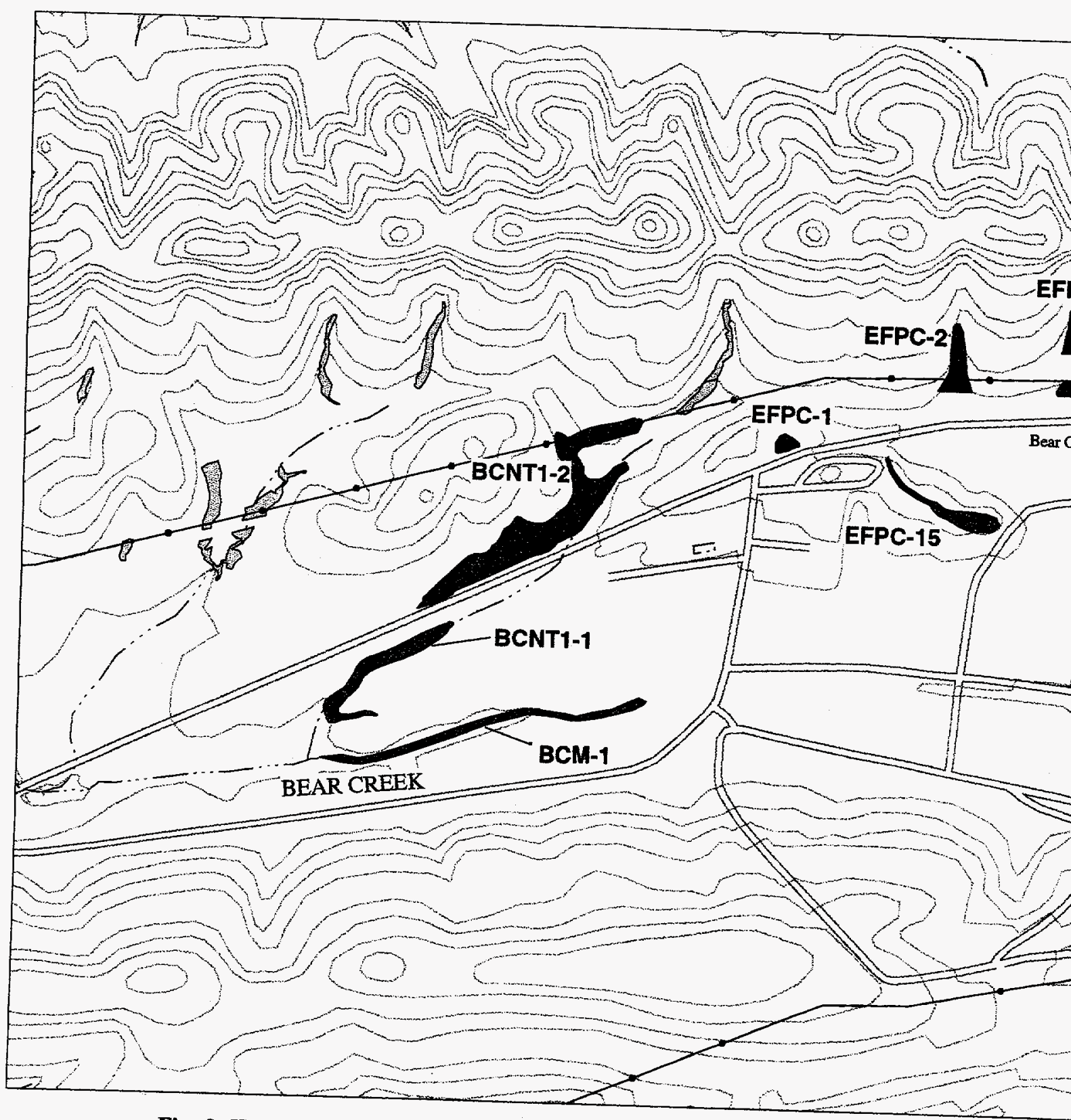

Fig. 2. Wetlands in the western half of the Upper East Fork Poplar Creek Operable Unit
Ridge Reservation, Oak Ridge, Tennesce 


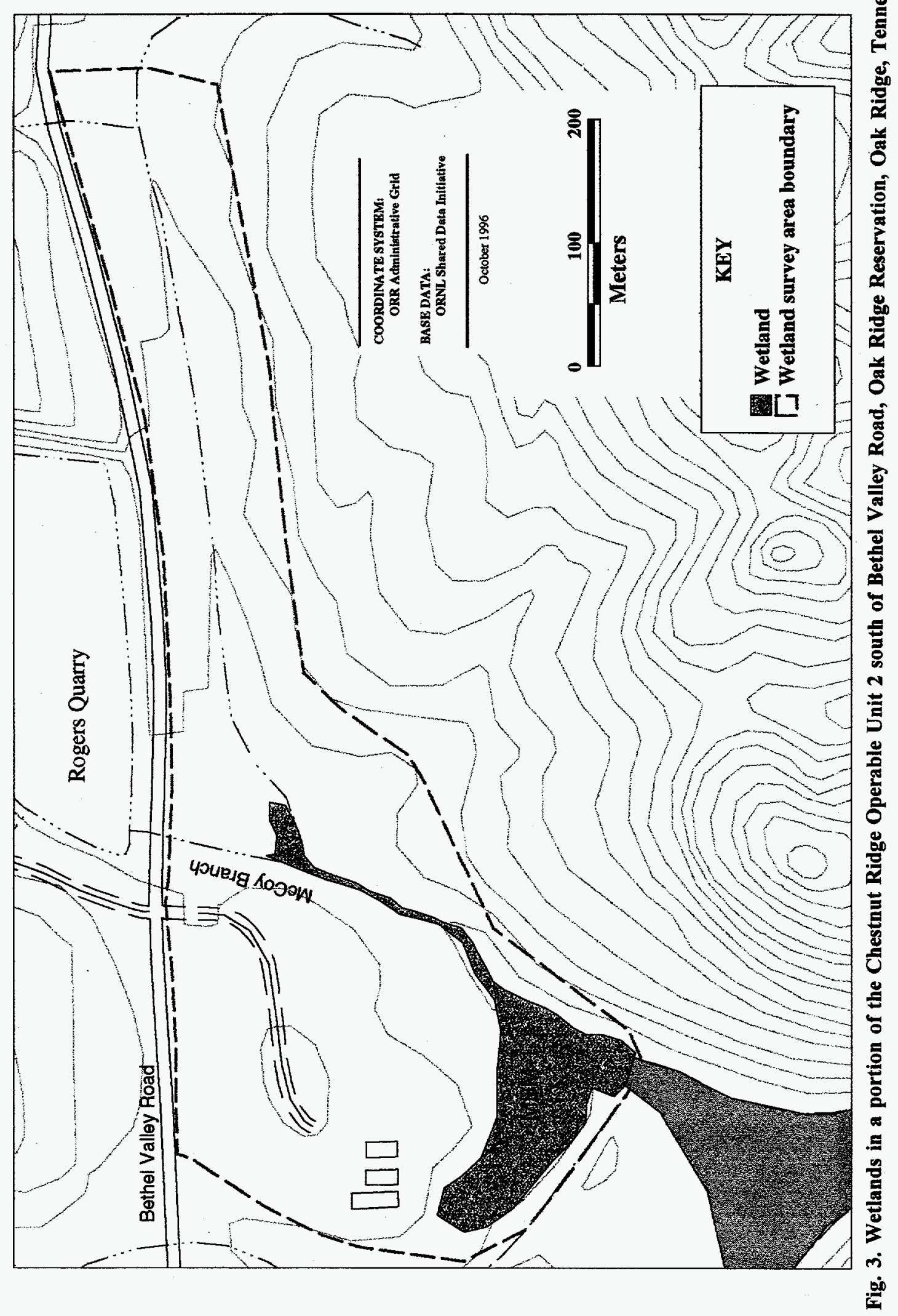


Table 2 lists some of the plant species that were either dominant or commonly found in the wetlands and their wetland indicator classifications (Reed 1988). The wetland class and approximate size for each wetland identified during this survey are listed in Table 3.

Table 2. Partial list of the dominant and common plant species and their wetland indicator classifications (Reed, 1988) identified in and adjacent to the wetlands identified during the wetland survey of selected areas the Y-12 Plant area of responsibility, May-July 1994

\begin{tabular}{|c|c|c|}
\hline Common name & Scientific name indicator & Regional \\
\hline \multicolumn{3}{|c|}{ Trees } \\
\hline Sweetgum & Liquidambar styriciflua & FAC \\
\hline Red maple & Acer rubrum & FAC \\
\hline Green ash & Fraxinus pennsylvanica & FACW \\
\hline Slippery elm & Ulmus rubra & FAC \\
\hline Black willow & Salix nigra & OBL \\
\hline \multicolumn{3}{|c|}{ Shrubs } \\
\hline Hazelnut & Corylus americana & FACU \\
\hline Elderberry & Sambucus canadensis & FACW- \\
\hline Buttonbush & Cephalanthus occidentalis & OBL \\
\hline Rose & Rosa sp. & not identifed to species \\
\hline \multicolumn{3}{|c|}{ Vines } \\
\hline Poison ivy & Toxicodendron radicans & FAC \\
\hline Hog peanut & Amphicarpaea bracteata & FAC \\
\hline Japanese honeysuckle & Lonicera japonica & FAC- \\
\hline \multicolumn{3}{|c|}{ Herbaceous species } \\
\hline Arrowleaf tearthumb & Polygonum sagittatum & OBL \\
\hline Cattail & Typha latifolia & OBL \\
\hline Cardinal flower & Lobelia cardinalis & OBL \\
\hline Lance-leaf loosestrife & Lysimachia lanceolata & FAC \\
\hline Ironweed & Vernonia noveboracensis & $\mathrm{FAC}+$ \\
\hline Jewelweed & Impatiens capensis & FACW \\
\hline Seedbox & Ludwigia $s p$ & OBL \\
\hline Dotted smartweed & Polygonum punctatum & FACW+ \\
\hline Smartweed & Polygonum sp. & FAC to OBL \\
\hline
\end{tabular}


Table 2. (continued)

\begin{tabular}{|c|c|c|}
\hline Common name & Scientific name indicator & Regional \\
\hline Beardtongue & Penstemon sp. & not identified to species \\
\hline Sheep sorrel & Rumex acetosella & FACUt \\
\hline Wild onion or wild garlic & Allium sp. & FAC or FACU \\
\hline Oxeye daisy & Chrysanthemum leucanthemum & not listed \\
\hline Butterfly weed & Guara biennis & FACU \\
\hline Johnson grass & Sorghum halepence & FACU \\
\hline \multirow[t]{2}{*}{ Crown vetch } & Coronilla varia & not listed \\
\hline & Sedges and rushes & \\
\hline Leathery rush & Juncus coriaceus & FACW \\
\hline Soft rush & Juncus effusus & FACW+ \\
\hline Blunt broom sedge & Carex tribuloides & FACW+ \\
\hline Woolgrass & Scirpus cyperinus & OBL \\
\hline Leafy bulrush & Scirpus polyphyllus & OBL \\
\hline \multirow[t]{2}{*}{ Soft-stem bulrush } & Scirpus validus & OBL \\
\hline & Grasses & \\
\hline Fowl manna grass & Glyceria striata & OBL \\
\hline Rice cutgrass & Leersia oryzoides & OBL \\
\hline Reed canary grass & Phalaris arundinaceae & OBL \\
\hline Orchard grass & Dactylis glomerata & FACU \\
\hline Barnyard grass & Echinachloa walteri & FACW- \\
\hline \multirow[t]{2}{*}{ Common reedgrass } & Phragmites australis & FACW \\
\hline & Ferns & \\
\hline Sensitive fern & Onoclea sensibilis & FACW \\
\hline
\end{tabular}

\subsection{UEFPC OU}

The UEFPC OU includes the entire Y-12 Plant main plant area bounded by Scarboro Road to the northeast; Chestnut Ridge and Pine Ridge to the southeast and northwest, respectively; and, to the southwest, the watershed divide between the UEFPC and Bear Creek watersheds. It includes the East Fork Poplar Creek (EFPC) upstream of Bear Creek Road. Fourteen wetlands were identified in the UEFPC OU. The wetlands are located in disturbed stream bottom and spring areas. 
Table 3. Classification ${ }^{a}$ and approximate size of wetlands identified in selected areas of the Y-12 Plant area of responsibility

\begin{tabular}{lcc}
\hline Wetland ID & $\begin{array}{c}\text { Approximate } \\
\text { area (ha) }\end{array}$ & Wetland classification $^{b}$ \\
\hline BCM-1 & 0.46 & PEM1 (altered) \\
BCNT1-1 & 0.48 & PSS1 (altered) \\
BCNT1-2 & 1.66 & PFO1C \\
EFPC-1 & 0.06 & PEM1 (altered) \\
EFPC-10 & 0.17 & PEM1 (altered) \\
EFPC-11 & 0.05 & PEM1 (altered) \\
EFPC-12 & 0.02 & PEM1 (altered) \\
EFPC-13 & 0.17 & PEM1 (altered) \\
EFPC-14 & 0.18 & PEM1 \\
EFPC-15 & 0.26 & PFO1h, PEM1h \\
EFPC-2 & 0.23 & PEM1 (altered) \\
EFPC-3 & 0.07 & PEM1 (altered) \\
EFPC-4 & 0.14 & PEM1 (altered) \\
EFPC-5 & 0.09 & PEM1 (altered) \\
EFPC-6 & 0.08 & PEM1 (altered) \\
EFPC-7 & 0.09 & PEM1 (altered) \\
EFPC-8 & 0.13 & PEM1 (altered) \\
EFPC-9 & 0.23 & PEM1 (altered) \\
MBM-1 & 1.57 & PEM1 (altered) \\
\hline
\end{tabular}

C Cowardin et al. 1979.

${ }^{b}$ PFO1 = palustrine, forested, broad-leaved, deciduous wetland (dominated by trees).

$\mathrm{PEMl}=$ palustrine, emergent, persistent wetland (dominated by grasses, sedges, rushes, and herbaceous species).

$\mathrm{C}=$ Seasonally flooded.

$\mathrm{h}=$ Diked/Impounded.

Note: (altered) refers to areas that have been cleared, partially filled, or otherwise disturbed.

\subsubsection{Southeast side of Bear Creek Road (Y-12 main plant area)}

Two wetlands were identified in this area (Figs. 1 and 2). One wetland (EFPC-13) is located at a seep adjacent to an EFPC subtributary in a small, wooded area between New Hope Cemetery and Bear Creek Road. The subtributary is in a deep channel with a bedrock bottom and begins at a pipe located at the base of a steep bank just inside the tree line. This is a perennial stream with groundwater as the primary water source. The stream also receives, via the pipe at the head of the stream, storm runoff from the Y-12 Plant garage area. This is a National Pollution Discharge Elimination System (NPDES) permitted outfall (Mick Wiest, personal communication, Sept. 30, 1994).

The wetland is on the southeast side of the stream at a seep. It is an emergent wetland, dominated by jewelweed, cardinal flower, and microstegium in the groundcover layer. Three large sycamores are at the wetland edge. Saplings of red maple, ironwood, and green ash occur throughout the wetland. The soil color is gleyed (N5/) and dark gray (10YR 5/1) with mottles and oxidized root channels. The soil was saturated and free water was in the soil boring. A forested wetland and ponded area (EFPC-14) is located in the southwestern half of the Y-12 Plant adjacent to Bear Creek Road. The streambottom area has been disturbed in the past and is surrounded by developed land. The pond has formed as the 
result of past fill and construction activities and is flanked by steep fill banks on three sides. No overflow or drainage pipes were evident, and it was not possible to ascertain where the water eventually drains.

No wetlands were identified in the remainder of the UEFPC south of Bear Creek Road. EFPC has been piped underground from its source to a location near the Y-12 Plant Portal 28. From Portal 28 to Lake Reality, EFPC has been channelized and either lined with stone "riprap" or concrete levees. From Lake Reality to Bear Creek Road, the channel is deep and the banks have steep sides. Vegetation has colonized both the natural and the stone-lined banks. This streambank vegetation is a mix of wetland-adapted and non-wetland-adapted species and includes immature black willow, sycamore, box elder, elm, sheep sorrel, Japanese honeysuckle, elderberry, lespedeza, oxeye daisy, crown vetch, field garlic, and Johnson grass. The vegetation community is not hydrophytic because numerous FACU and UPL species are among the dominant species. The morphology of the stream is such that the banks are flooded only during storm events and only for the duration of the storm runoff. Therefore, the wetland hydrology criteria was not met.

\subsubsection{Northwest Side of Bear Creek Road}

This area includes the land from Bear Creek Road to the top of Pine Ridge. The topography and vegetation of this area has been altered to accommodate powerline corridors and Y-12 Plant security. The forest vegetation has been cleared for approximately one-quarter to one-half the distance up the side of Pine Ridge. The cleared area is now maintained in grass and other nonnative herbaceous species. Kudzu has covered some of the steep slopes, especially near the water treatment plant. Ten EFPC tributary streams originate on the lower slopes of Pine Ridge in the altered area. All of the tributaries have had large portions of their lower reaches piped and/or filled. Those sections of the stream bottoms not filled or piped have been filled with rock. In some cases, the stream channel has been buried beneath the rock and is not visible. Emergent wetlands and scrub/shrub wetlands were identified in the stream bottom remnants (EFPC-1 through EFPC-13).

Four of the altered stream bottoms were surveyed for wetlands in 1992 by Oak Ridge National Laboratory Environmental Sciences Division staff and were subsequently determined by the Tennessee Department of Environment and Conservation (TDEC) to be Waters of the State (e.g., open water and wetlands) (Appendix A, Letter from William Childres, TDEC, to Robert Spence, Y-12 Area Manager, 12/7/92). By using the TDEC determination as a guide, it is highly probable that the remaining six areas identified in this survey would also be considered Waters of the State.

Most of the wetlands (EFPC-11, $-10,-9,-7,-8,-5,-4,-3,-2,-1$ ) are surrounded on three or four sides by grass that is regularly mowed. One of the wetlands (EFPC-6) consists of several seeps in a densely vegetated wetland in an unmaintained area on the north side of the water tank access road. Another wetland (EFPC-12), located in a depression downslope of the water treatment plant, is surrounded by very steep, kudzu-covered slopes. The easternmost wetland (EFPC-13) is a relatively undisturbed, wooded area that has kudzu encroaching on three sides.

EFPC-7 is a wetland swale that begins on the edge of a parking lot located downslope from the water towers. The swale continues around the eastern edge of the parking lot and empties onto the maintained grass south of EFPC-8. The volume and rate of flow of water through this swale and across the grassy area suggested that the water source was not a spring (the flow rate appeared to be greater than at the other springs observed that day); however, the water source was not identified during this survey. 
Wetland hydrology was present in all of the remnant stream bottoms identified as wetlands. Flowing and/or standing water, saturated soils, seeps, and/or springs were evident in all of the remnant stream bottoms. In the rock-filled stream bottoms, at least one source of water was identified at headwater springs, which were not covered by the rocks. Where the rocks covered the stream channels, water could be heard flowing underneath the rocks. EFPC-6, located on the north side of the paved access road to the water tanks, receives water from several seeps. There was no surface outlet for the water from this wetland, and it is possible that the water seeps underground to reemerge at a point farther downslope.

The dominant vegetation in the stream remnant wetland areas includes black willow, rice cutgrass, seedbox, and dotted smartweed. Other species include elderberry, woolgrass, soft rush, cattail, fox sedge, and sallow sedge.

In many of the stream bottoms, a soil sample could not be extracted because of the rock layer. Therefore, in these areas, the presence of hydric soils was inferred from the presence of water and hydrophytic vegetation. Hydric soils were directly observed in four areas (EFPC-13, -12, -6, and -5). The soils included gray (10YR 6/1,5/2, and 6/2) clay and silt loams and a light gray (10YR 7/1) sandy silt. The soil samples had reddish-brown mottles (10YR 5/8 and 7/5YR 5/8) and manganese concretions.

\subsection{BEAR CREEK OPERABLE UNIT: NORTH TRIBUTARY 1 AND WEST END ENVIRONMENTAL MANAGEMENT AREA}

The survey area included the watershed of Bear Creek from Bear Creek Road upstream through the Y-12 Plant West End Environmental Management Area and the Bear Creek North Tributary (BCNT)1 catchment south of the powerline right-of-way (Fig. 1). Wetlands in the rest of the Bear Creek watershed have been mapped based on survey work conducted in 1992 (Rosensteel and Trettin 1993). Wetlands identified during the 1992 survey in the upper catchment of BCNT1 and in the BCNT2 catchment are shown on Fig. 1.

A forested wetland (BCNT1-2, Fig. 1) was identified in the North Tributary 1 drainage between the power line right-of-way and Bear Creek Road. This area is relatively undisturbed and supports a second-growth sweetgum/red maple forest in the bottomland. The dominant and common species include sweetgum, red maple, green ash, slippery elm, leathery rush, cutgrass, fowl manna grass, and arrowleaf tearthumb. Other species present in the wetland include sallow sedge, sensitive fern, cardinal flower, poison ivy, hog peanut, hazelnut, blunt broom sedge, and lance-leaved loosestrife.

The soils are a gray to dark gray (10YR 6/1 and 4/1) silt loam with prominent mottles and manganese concretions. There was flowing water in the stream channel, and the soil was saturated across the entire wetland. Water was observed in several of the soil auger holes at a depth of 0 to 6 in. The primary water source is groundwater. There are several distinct seeps and springs within the wetland.

BCNT1 flows through a culvert under Bear Creek Road. In the section south of the road, the riparian area is flanked by the Bear Creek road berm and by the gravel and paved areas of the West End Environmental Management Area. There are emergent and scrub/shrub wetlands along BCNT1 in this reach (BCNT1-1, Fig. 1). Vegetation includes green ash, black willow, box elder, red maple, elderberry, jewelweed, cattail, bulrush, and an unidentified species of grass. This section of the stream 
has a several-inch-thick layer of silt. Most of this siltation may be the result of soil erosion from the development of the adjacent waste management area. The downstream reach of BCNT1 has been piped to the confluence with Bear Creek.

On aerial photos of this area, Bear Creek can be identified as a narrow band of vegetation winding through the unvegetated, highly developed West End Environmental Management Area. The streambed is several feet lower in elevation than the surrounding developed land and is flanked by densely vegetated banks. Progressing from the head of the stream to the Environmental Management Area fence there are (1) a small, emergent wetland dominated by common reedgrass, (2) small, emergent wetlands on narrow shelves within the stream bottom, (3) a cattail/willow wetland on both sides of a paved road crossing, (4) a short section without wetlands, and (5) an emergent wetland upstream of the fence. The dominant species are black willow, common reedgrass, jewelweed, cattail, barnyard grass, smartweed, and sedges. Because of the difficulties inherent in defining the boundaries of these individual wetland areas on the existing 20-ft contour maps, the entire length of Bear Creek in the West End Environmental Management Area was mapped as wetland (BCM-1, Fig. 1).

No soil samples were taken in or around Bear Creek either because either the area was cordoned off with yellow-and-magenta radiation area chain or the contamination status of the sediments was not known to the field investigator. Wetland determinations were made on the basis of the dominance of hydrophytic vegetation and direct observation of wetland hydrology.

No wetlands were identified along the reach of Bear Creek between the West End Environmental Management Area fence and Bear Creek Road. Bear Creek has steep, deeply cut banks in this reach, and although the areas adjacent to the stream are occasionally flooded, the floodwaters usually recede quickly, and the floodplain soils appear to be well-drained.

\subsection{CHESTNUT RIDGE OU 2: MCCOY BRANCH SOUTH OF BETHEL VALLEY ROAD}

The area in which the survey was conducted was the McCoy Branch bottomland in the reach between Bethel Valley Road and the McCoy Branch Embayment (Fig. 3). McCoy Branch flows roughly north to south across the site and empties into the McCoy Branch embayment of the Clinch River-Melton Hill Reservoir. A subtributary enters the survey area through a culvert under Bethel Valley Road and joins McCoy Branch in the northern half of the survey area. A second subtributary enters McCoy Branch from the west immediately upstream of the embayment.

The McCoy Branch bottomland area has been disturbed and altered for various agricultural uses in the past, including private farming, government projects that required agricultural land (i.e., livestock pastures), and two utility rights-of-way. The majority of the site is pasture and hayfields. The dominant species are planted pasture grasses and lespedeza, which were probably first planted as livestock forage. Other species include butterflyweed, goldenrods, and beardtongue. Trees and shrubs occur along McCoy Branch and in depressions (probable groundwater seeps) in the old pastures and include green ash, black willow, sycamore, buttonbush, and rose. In the depressions along McCoy Branch and its tributary and in low-lying areas, the dominant herbaceous species include reed canary grass, sedges, and soft rush.

One large wetland was identified on the site. The northern extent of the wetland begins in a triangle of land at the confluence of $\mathrm{McCoy}$ Branch and the first subtributary where a wetland/upland mosaic was formed by depressions and shallow surface channels interspersed with slightly higher 
elevation ground. The vegetation in the depressions and surface channels includes black willow, green ash, sycamore, rose, buttonbush, sedges, and hog peanut. The soil characteristics vary with microtopography with soil chromas of 1 and 2 ; mottles and manganese concretions in the depressions and channels; and chromas of 3 , with some mottling, on the higher ground. The soil within the channels and depressions was moist at the surface; however, no other direct evidence existed of wetland hydrology observed on the day of the survey. This is a human-induced, atypical situation wetland.

The wetland continues in the downstream direction as scrub/shrub and emergent wetlands of varying width (approximately 2 to $15 \mathrm{~m}$ ) in the riparian zone and on alluvial soils in the streambed of McCoy Branch. The dominant species include black willow, sycamore, reed canary grass, and sedges. The soil has a chroma of 1 or 2 with mottles and manganese concretions.

Continuing in the downstream direction, the wetland area widens and extends into an old pasture. The species in the pasture area include reed canary grass, soft rush, and ironweed. The soil in the meadow area and in the downstream riparian area of McCoy Branch includes a 10YR 6/1 (gray) clay loam with mottles and manganese concretions. Hydrologic evidence includes saturated soils; surface channels; ponded water; and dried, cracked soil in a shallow depression. The water sources probably include perched runoff, direct precipitation, and groundwater seeps. There are also isolated, small depressions in the pasture, adjacent to the stream fringe wetlands, in which are found black willow and sedges and saturated soils.

\section{SUMMARY}

Wetland surveys were conducted during June and July 1994 in the EFPC OU, a portion of the Bear Creek OU, and the Chestnut Ridge OU 2 in the section south of Bethel Valley Road. Wetlands were identified according to the USACE methodology (USACE 1987) and were classified according to the system developed by Cowardin et al. (1979).

In the UEFPC OU, a total of 15 wetlands were identified. Thirteen wetlands were identified in remnant stream channels on the north side of Bear Creek Road. At one time, these areas were forested stream bottoms that drained to EFPC; however, the extensive land alteration and construction that have occurred at the Y-12 Plant have left only remnants of these bottoms. Two of the wetlands are south of Bear Creek Road and are altered stream channels in small fragments of forest. No wetlands were identified along EFPC in the section between the Bear Creek Road/Scarboro Road intersection to the farthest upstream point at the Y-12 Plant Portal 28.

In the Bear Creek OU portion of the survey area, a relatively undisturbed, forested wetland was identified in the stream bottomland of BCNT1 between Bear Creek Road and the powerline right-of-way. Within the Y-12 Plant West End Environmental Management Area, emergent and $\mathrm{scrub} / \mathrm{shrub}$ wetlands were identified along BCNT1 and within the banks of Bear Creek. There are no wetlands along Bear Creek in the reach between the Y-12 Plant West End Environmental Management Area fence and Bear Creek Road.

Emergent and scrub/shrub wetlands were identified in the riparian area and in old pastures in the McCoy Branch bottomland in Chestnut Ridge OU 2 between Bethel Valley Road and the McCoy Branch embayment. The dominant vegetation species are primarily grasses and herbaceous species; 
however, there are trees and shrubs in the stream riparian zone and in depressions throughout the bottomland area.

\section{REFERENCES}

Childres, W. H. December 7, 1992. Manager, Waste Management, DOE-Oversight Division, Tennessee Department of Environment and Conservation, letter to Robert Spence, Y-12 Site Manager, Oak Ridge, Tenn.

Cowardin, L. M., V. Carter, F. C. Golet, and E. T. LaRoe. 1979. Classification of Wetlands and Deepwater Habitats of the United States, FWS/OBS-79/31, U.S. Fish and Wildlife Service, Washington, D.C.

Kollmorgen Instrument Corp., MacBeth Div. 1990. Munsell Soil Color Charts, Newburgh, NY.

Reed, P. B. 1988. National List of Plant Species That Occur in Wetlands: Tennessee, NERC$88 / 18.42$, U.S. Fish and Wildlife Service.

Rosensteel, B. A. October 8, 1992. Internal Memo to Cory Wilkinson, Y-12 Health, Safety, and Environment Accountability Division, Preliminary Wetland Determination for Four Sites at $Y$ 12.

Rosensteel, B. A., and C. C. Trettin. 1993. Identification and Characterization of Wetlands in the Bear Creek Watershed, Y/TS-1016, Oak Ridge National Laboratory, Oak Ridge, Tenn.

U.S. Army Corp of Engineers. 1987. Wetlands Delineation Manual, Technical Report Y-87-1, Waterways Experiment Station, Vicksburg, MS. 
Appendix A 


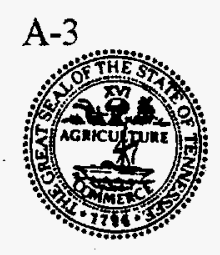

STATE OF TENNESSEE

\author{
DEPARTMENT OF ENVIRONMENT AND CONSERVATION \\ DOE OVERSIGHT DIVISION \\ 761 EMORY VALLEY DRIVE \\ OAK RIDGE, TENNESSEE 37830-7072
}

December 7, 1992

Mr. Robert Spence

Y-12 Site Manager

P.O. Box 2001

Oak Ridge, TN 37831-8535

Dear Mr. Spence:

During a site inspection on October 23, 1992 Barbara Rector and Mark Carder looked at five different areas to verify the presence or absence of wetlands. The five sites that were reviewed had previously been delineated as wetlands by ORNL personnel. The purpose of DOE-O's inspection was to inform DOE and MMES of the state's position on the wetland areas in question. The findings that were made by DOE-O personnel were discussed with the Division of Water Pollution Control, Natural Resources section for concurrence.

The first site was located in the eastern portion of $\mathrm{Y}-12$, adjacent to the west side of Lake Reality. Railroad tracks border the eastern edge of the wet area. There is a manmade swale located at this site which has created conditions amenable for the growth of wetland vegetation. Despite the presence of wetland conditions, the state would not consider this site to be in need of protection as a wetland resource. Therefore the proposed work could be conducted without obtaining a state Aquatic Resource Alteration Permit (ARAP). However, please be reminded that all work being done to install the french drain and the subsequent fill material, must be completed with strict erosion control measures in place. And, as was mentioned to $\mathrm{Mr}$. Halburnt during the inspection, the DOE-O office should be contacted before construction begins so that personnel can inspect the area to ensure that all necessary erosion controls are in place.

The remaining sites that were looked at were located along Bear Creek Road. Wetland vegetation, in combination with a surface water source were present at all of the sites viewed. Stream tributaries, with flowing water, were located at three of the Bear Creek sites. 
The proposed work for these sites; cover with an impermeable plastic liner, soil fill and revegetation with grass seed, that was described to DOE-O personnel are unfavorable for permitting under the State's ARAP system. The primary goal for wetland and aquatic system protection is avoidance of the resource. Permits are typically granted only if alterations to the wetland cannot be avoided. In this case, the alteration is solely for aesthetic purposes and would not be considered an unavoidable condition. Several of the areas that DOE-O personnel were shown had already undergone unpermitted alterations to aquatic resources. These areas should be protected against any further disturbances or alterations.

At the site near Bear Creek portal, where there are two wetland areas separated by a strip of grass, an eight to ten foot buffer area should be maintained around the wetlands. The buffer zone should start from the edge of the mow area as it stands today, and extend outward away from the wetlands.

Through this letter, DOE-O wishes to inform you of the state's position on this matter. In no way does this prevent you from applying for an ARAP with the Division of Water Pollution Control.

If you have any questions concerning these determinations or the site visit, please feel free to contact me or Barbara $H$. Rector at 481-0995. Thank you.

Sincerely,

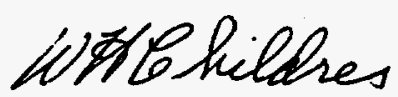

william H. Childres

Manager

Waste Management

DOE-Oversight Division

CC: J.D. Kelly, Y-12

B. Rosensteel, ORNL

R. Baker, Nat. Res. - WPC

wm0162.01 


\section{DISTRIBUTION}

1. L. V. Asplund

2. L. T. Cusick

3. C. S. Haase

4. L. M. Houlberg

5. J. A. Johnston

6-7. D. M. Matteo

8. H. C. Newsom

9. P. T. Owen

10. D. E. Watson

11. M. C. Weist

12. ER Document Management Center-RC

13. M. K. Leslie, CDM Federal Programs Corporation, 800 Oak Ridge Turnpike, Suite 500, Oak Ridge, Tennessee 37830

12. E. Leming, Tennnessee Department of Environment and Conservation-DOE Oversight Division, 761 Emory Valley Road, Oak Ridge, Tennessee 37830

14. D. Moss, Science Applications International Corporation, 301 Laboratory Road, Oak Ridge, Tennessee 37830

15-19. B. A. Rosensteel, JAYCOR, 601-D Scarboro Rd., Oak Ridge, Tennessee 37830 